\title{
The first central nervous system autopsy in Southern Brazil
}

\author{
Primeira autópsia do sistema nervoso central no sul do Brasil \\ Sérgio Monteiro de Almeida1,2, Gabriel L.O. Salvador', Thiago H. Roza' , Lucia Noronha', Luiz Fernando \\ Bleggi Torres ${ }^{1,2}$
}

\begin{abstract}
Objective: The history of Anatomical Pathology in the state of Paraná, in southern Brazil, is closely linked with the foundation of the Universidade Federal do Paraná (UFPR). This study identified the first central nervous system (CNS) clinical autopsy performed by the Department of Anatomical Pathology of the UFPR. Methods: This study reviewed the autopsy report archives of the Hospital de ClínicasUFPR from 1951 onward. The clinical anatomy interpretations of the autopsy report and possible etiologic agents were discussed. Result: The first adult clinical autopsy with CNS study was performed on April 23, 1952 on a 45-year-old man with lobar pneumonia with abscesses complicated by bacterial meningitis. Conclusion: This case was the first CNS clinical autopsy performed in the state of Paraná and, possibly, in southern Brazil. The death was due to an infectious disease, which was the main cause of death in Brazil in the 1950 s.
\end{abstract}

Keywords: Meningitis, autopsy; central nervous system; pneumonia; lung abscess.

\section{RESUMO}

Objetivo: A história da Anatomia Patológica no Estado do Paraná, sul do Brasil, está ligada com a fundação da Universidade Federal do Paraná (UFPR). Este estudo identificou a primeira autópsia clínica do sistema nervoso central (SNC) realizada pelo Departamento de Anatomia Patológica da UFPR. Métodos: Foi realizada revisão dos arquivos dos relatórios de autópsia do HC-UFPR, desde 1951. As interpretações anátomo-clínicas do laudo da autópsia e os possíveis agentes etiológicos foram discutidas. Resultado: A primeira autópsia clínica em adulto com estudo do SNC foi realizada em 23 de abril de 1952. Um homem de 45 anos com pneumonia lobar com abscessos pulmonares, complicada com meningite bacteriana. Conclusão: Este caso é a primeira autópsia clínica em adulto com estudo do SNC do estado do Paraná e possivelmente do Sul do Brasil. A causa da morte foi devido a uma doença infecciosa, as principais causas de óbito no Brasil nos anos 50 .

Palavras-chave: Meningite; autópsia; sistema nervoso central; pneumonia; abscesso pulmonar.

The history of Anatomical Pathology in the state of Paraná, southern Brazil, is linked to the development of the Universidade Federal do Paraná (UFPR). Officially founded in 1912, it was the first university in Brazil. The UFPR originated from the School of Arts and Industry founded by Antonio Mariano de Lima (Trás-os-Montes, Portugal, 1858 - Manaus, Brazil, 1942). Despite its apparent lack of success, the School of Arts and Industry produced important artists, such as João Zaco Paraná (1884-1961) and João Turin (1878-1949), as well as giving rise to the UFPR. Many of the UFPR founders were faculty members of the School of Arts and Industries; among them Victor Ferreira do Amaral (1862-1953), who taught Anatomy classes and was its vice-director. He was the first dean of the UFPR, when it became a federal university ${ }^{1}$.
The School of Medicine of the UFPR was founded by the physicians Victor do Amaral, Nilo Cairo (1874-929), Petit Carneiro (1876-1940), and Alfredo de Assis Gonçalves (1884-1984). In 1913, Pathology as a discipline and medical specialty was first taught by several nonpathologist professors under the name of Anatomical Pathology and Physiology $y^{2,3}$.

In 1935, Dr. Paulo de Queiroz Telles Tibiriçá (1903- ?) was hired by the UFPR from the University of São Paulo, where he specialized in Pathology. He was assigned to develop the Department of Anatomical Pathology and Physiology. He created a museum of anatomy specimens, microscope slide collections and organized clinicopathological meetings. The department was inaugurated on September 7, 1935,2,3 later,

1Departamento de Patologia Médica, Universidade Federal do Paraná, Curitiba PR, Brasil;

${ }^{2}$ Faculdades Pequeno Príncipe, Instituto de Pesquisa Pelé Pequeno Príncipe, Curitiba PR, Brasil.

Sérgio Monteiro de Almeida (iD) https://orcid.org/0000-0001-5690-105X

Correspondence: Sérgio Monteiro de Almeida; Hospital de Clínicas - UFPR, Seção de Virologia, Setor Análises Clínicas; Rua Padre Camargo, 280; $80060-240$ Curitiba PR, Brasil; E-mail: sergio.ma@ufpr.br

Conflict of interest: There is no conflict of interest to declare.

Received 05 July 2018; Accepted 23 September 2018. 
Professor Tibiriçá moved to the Universidade Federal do Rio Grande do Sul, Porto Alegre in 1944".

During these early years, autopsies were performed in the Santa Casa Hospital, where the UFPR medical students received training before the Hospital de Clínicas (HC-UFPR) was founded in 1961. The Department of Anatomical Pathology and Physiology moved to the HC-UFPR this same year ${ }^{2,3}$.

The objective of the present study was to identify and report the first central nervous system (CNS) clinical autopsy performed by the Department of Anatomical Pathology and Physiology of the UFPR. This study will contribute to the register and historical analysis of the evolution of Neuropathology in Brazil and South America.

\section{METHODS}

The autopsy report archives of the Department of Anatomical Pathology of the HC-UFPR were reviewed from 1951 onward. Other possible clinical anatomy interpretations, different from the one at the time, are reviewed and discussed.

\section{RESULTS}

In the archives of the Department of Anatomical Pathology and Physiology, of the HC-UFPR, there are a total of 13,986 autopsy examinations, performed between 1951 and 2014. This period includes autopsies performed before the foundation of the HC-UFPR.

The first autopsy performed by the Department of Anatomical Pathology and Physiology of the School of Medicine of the UFPR was performed on November 18, 1951 on a 32-yearold white widowed woman. The cause of death was pulmonary tuberculosis (Figure 1). The first adult CNS autopsy was no. 70, performed on April 23, 1952. The case was a 45-year-old white man who was married and had worked as a bill collector. The cause of death was acute purulent meningitis (bacterial meningitis) associated with lobar pneumonia with abscesses (Figure 2). Both autopsies were performed by Prof. Dr. Ruy Leal.

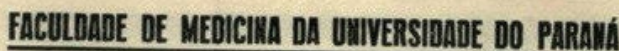

\section{DEPARTAMENTO DE ANATOMIa PATOLÓGICA SERVIÇO DE VERIFICAÇ̃̃o DE ÓBITOS}
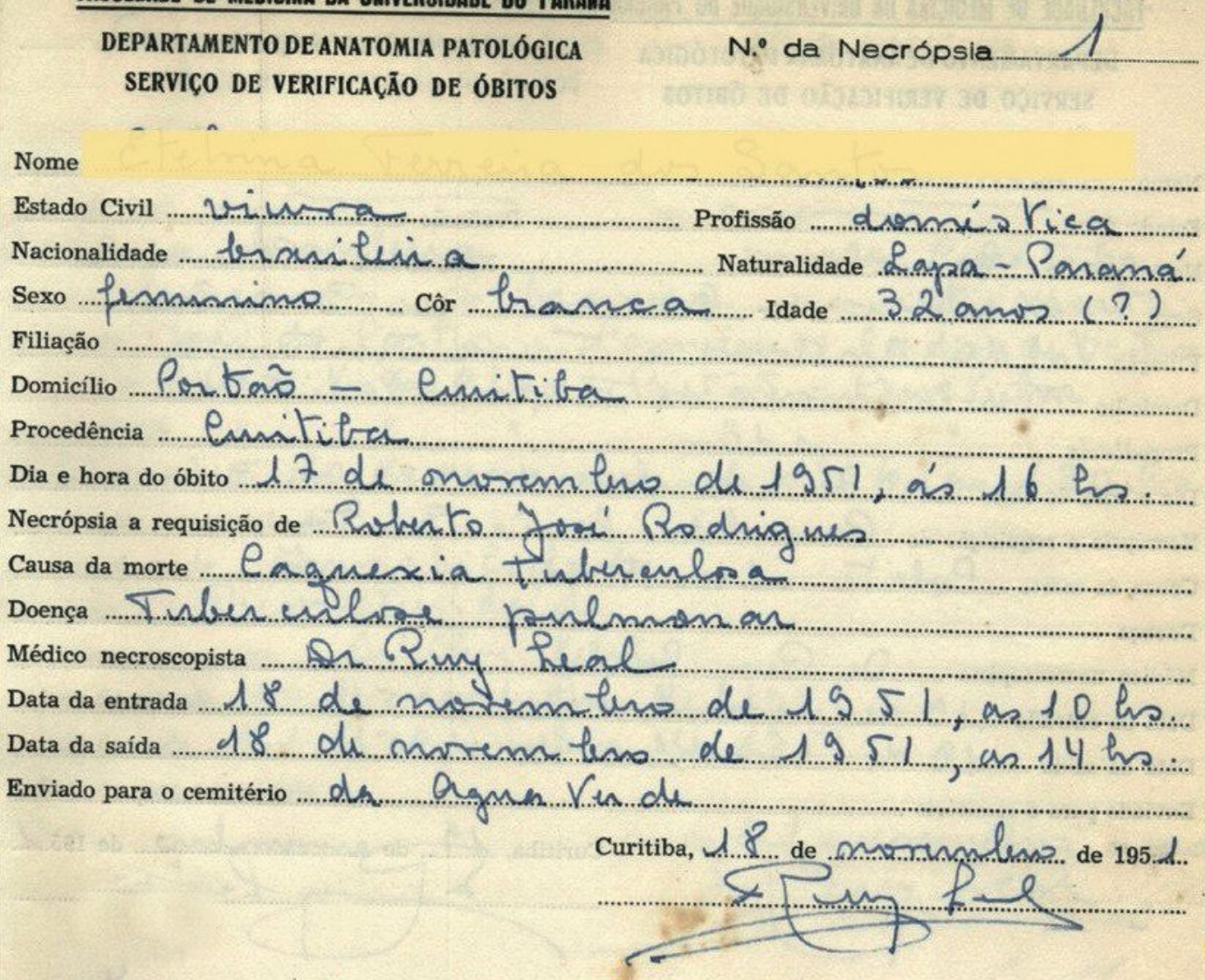

Figure 1. The first clinical autopsy performed by the Department of Anatomical Pathology of the School of Medicine of the UFPR, was performed on November 18, 1951, on a 32-year-old white widowed woman. The cause of death was pulmonary tuberculosis. The pathologist who signed was Prof. Dr. Ruy Leal. According to the World Health Organization, tuberculosis, while no longer among the 10 leading causes of death, still remained among the 15 leading causes worldwide in $2012^{9}$. 

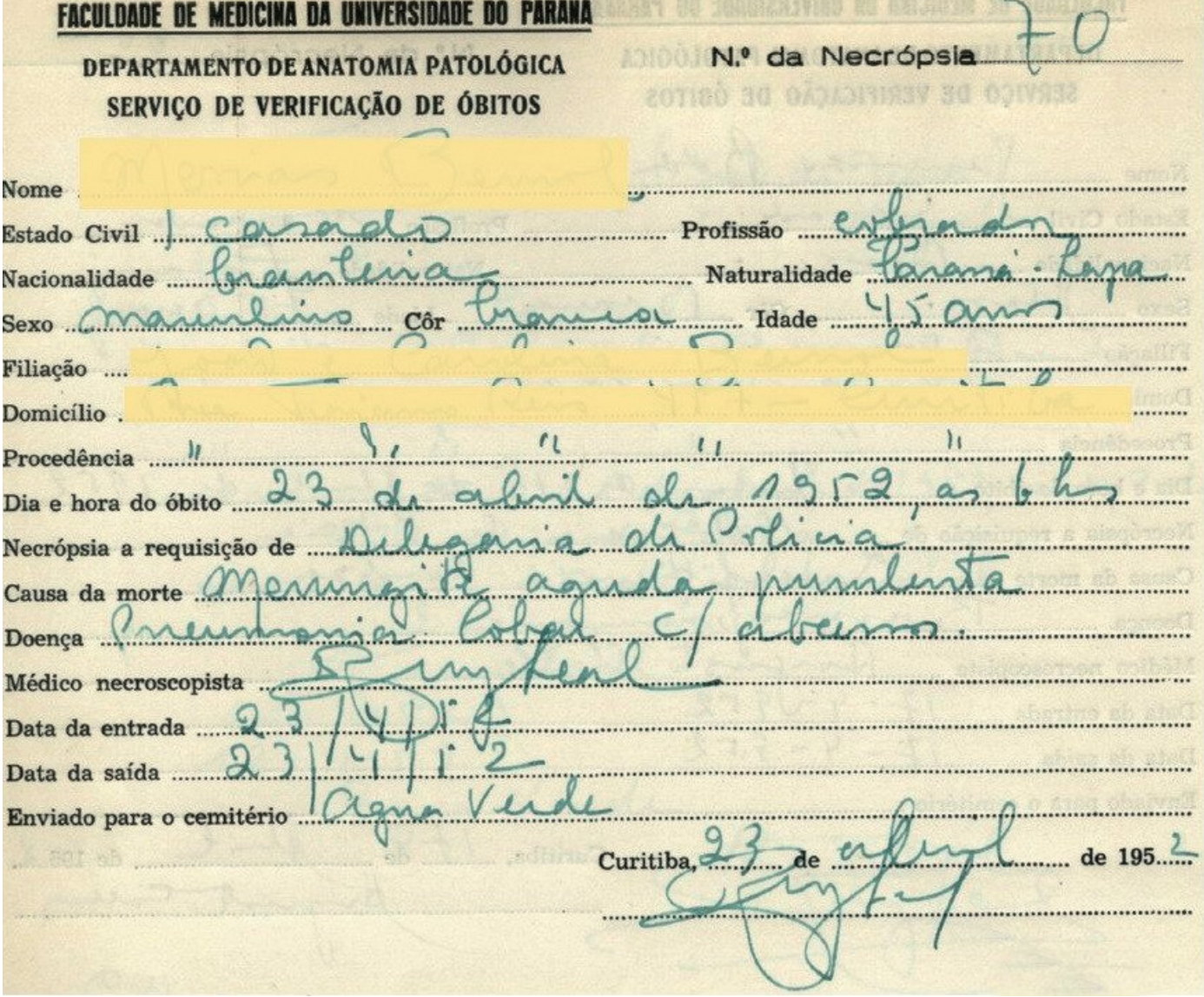

Figure 2. The first adult CNS clinical autopsy report, autopsy no. 70, was performed on April 23, 1952. The cause of death was acute purulent meningitis associated with lobar pneumonia with abscesses. The pathologist who signed was Prof. Dr. Ruy Leal.

\section{DISCUSSION}

No records exist of autopsies performed in the UFPR during the early period (1913-1950). Autopsy services in other cities in Paraná state started in the 1960s and '70s' strong evidence that autopsy no. 70 was the first CNS clinical autopsy study performed in an anatomical pathology university laboratory in Paraná state, as well as in southern Brazil, as Professor Tibiriçá moved from the UFPR to the Universidade Federal do Rio Grande do Sul to organize the Anatomical Pathology service in the state of Rio Grande do Sul ${ }^{4}$.

According with the autopsy report, this case was considered at the time, by Dr. Ruy Leal, as lobar pneumonia complicated by lung abscesses followed by meningitis; however, the etiologic agent was not identified. The main causes of pulmonary abscesses are anaerobic bacteria (46\%), comprising Peptostreptococcus sp (12\%), Fusobacterium nucleatum (5\%), and Prevotella sp. (1\%); while $11 \%$ are aerobic, comprising Staphylococcus aureus (4\%), Klebsiella pneumoniae (3\%), Streptococcus pneumoniae serotype 3 (1\%), Pseudomonas aeruginosa; and polymicrobians (43\%) (aerobic and anaerobic) $)^{5}$. Most lung abscesses are caused by aspiration of oral secretions in patients with impaired consciousness. The meningitis was secondary to septicemic dissemination of bacteria to the brain. Lung abscesses constantly seed bacteria into the bloodstream, increasing the patient's risk of brain infection and meningitis ${ }^{6}$ (Figure 3A). Other possible interpretations are discussed in Figure 3B and $\mathrm{C}$.

Meningitis was first reported by Thomas Willis (16211675). Gaspard Vieusseux (1746-1814) and Andre Matthey (1778-1842) in Geneva, and Elisa North (1771-1843) from Massachusetts, described epidemics of meningococcal meningitis. William Mestrezat (1883-1929) and H. Houston Merritt (1902-1979) later compiled large series of CSF profiles in meningitis. Successful meningitis treatment began with the introduction of serum therapy for meningococcal meningitis by Georg Joachmann (1874-1915) in Germany, and Simon Flexner (1863-1946) in the United States. Antibiotic therapy began in the 20th century with use of sulfonamides by Francois Schwentker (1904-1954) and penicillin by Chester Keefer (1897-1972). Vaccination against meningitis debuted in the early 20th century and progressed to the development of vaccines against $N$. meningitidis and $H$. influenzae, which remain mainstays of modern Medicine ${ }^{7}$.

Infectious diseases were the cause of death in both autopsies presented in this paper (Figures 1 and 2), consistent with the predominant causes of mortality in Brazil during this period. Mortality decreased significantly from the 1970s. While 


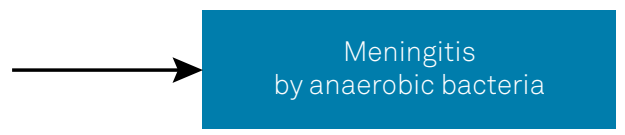

b)

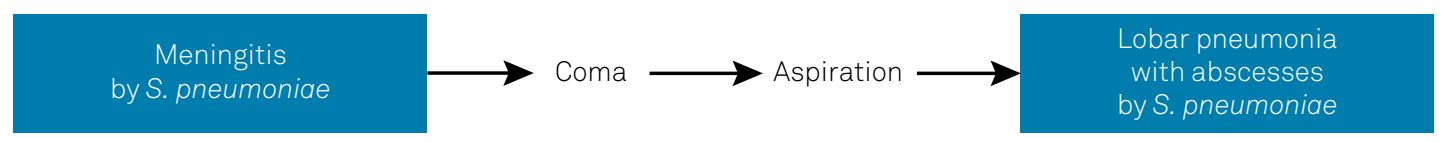

c)
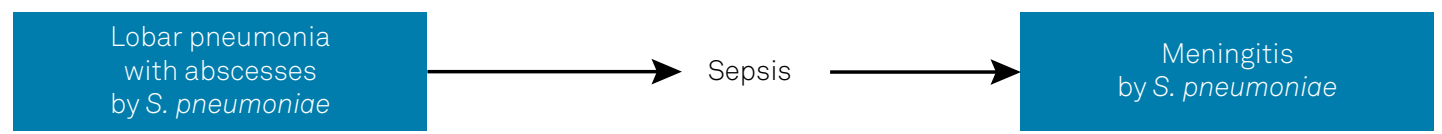

Figure 3. Clinical anatomical interpretations of the autopsy report and possible etiologic agents. We do not have the clinical history of the patient to best interpret the autopsy report, so this is a speculative discussion. A. Interpretation considered at the time, by Dr. Ruy Leal, as lobar pneumonia complicated by lung abscesses followed by meningitis; the main causes of lung abscesses are anaerobic bacteria, complicated by meningitis. B. Another probable interpretation, communitarian bacterial meningitis caused by Streptococcus pneumoniae, based on the patient's age, complicated by impaired consciousness and aspiration pneumonia with abscesses. C. S. pneumoniae pneumonia, the main etiologic agent of lobar pneumonia, complicated by lung abscesses; followed by sepsis and dissemination of $S$. pneumoniae to the brain, and meningitis. This hypothesis is less probable. S. pneumoniae, as a cause of lung abscess occurs in only $1 \% 5$.

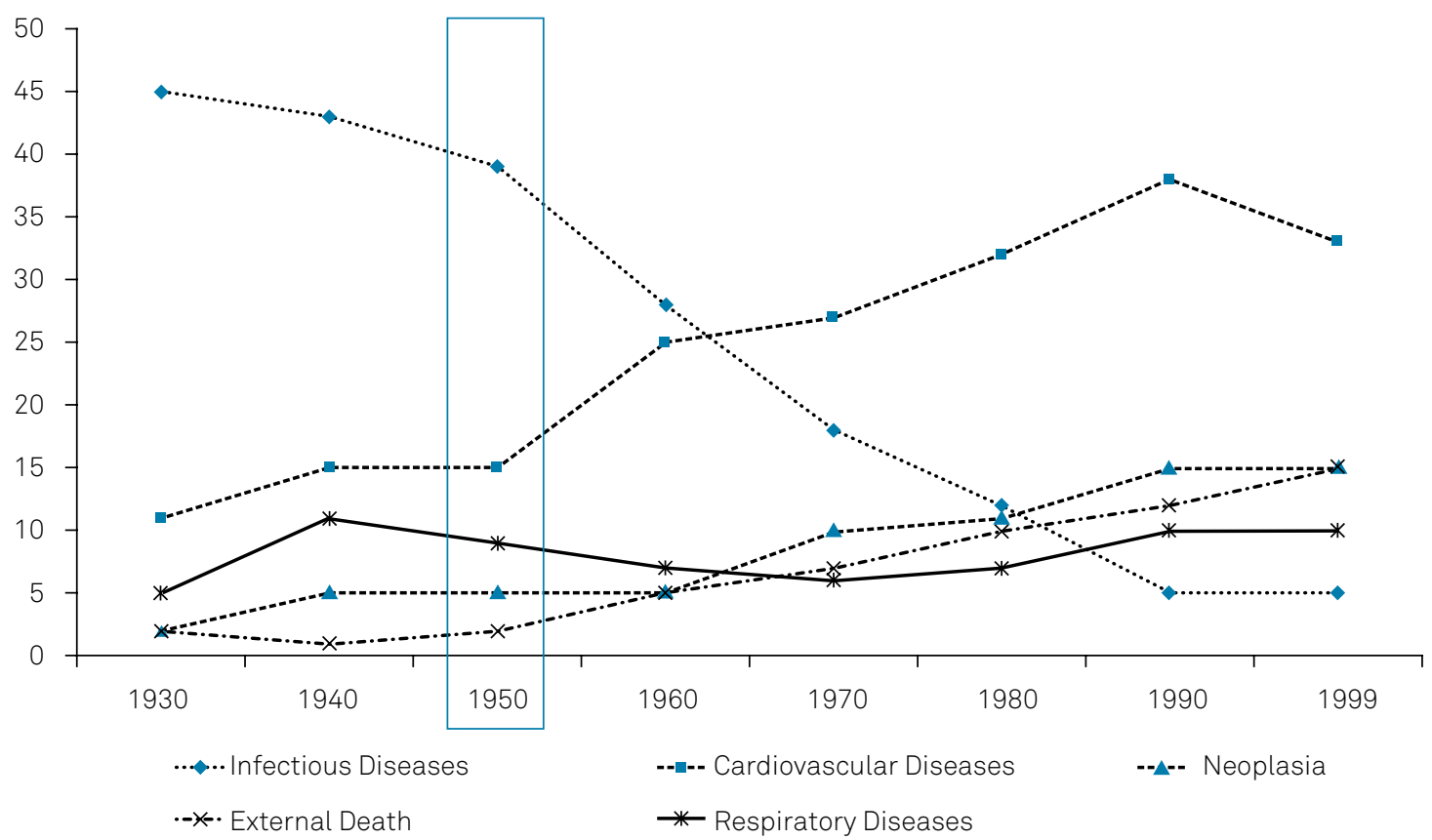

Figure 4. Proportional mortality according to causes among capital cities in Brazil, 1930-1999 (modified from Carmo et al. ${ }^{\text {) }}$.

mortality from infectious and parasitic diseases has declined, mortality from chronic degenerative causes and injuries related to accidents and violence have increased ${ }^{8}$ (Figure 4).

In conclusion, we report on the earliest adult CNS autopsy case in the records of the Department of Anatomical
Pathology and Physiology of the HC-UFPR, this being the first CNS clinical autopsy performed in the state of Paraná, with strong evidence that it was also the first in southern Brazil. The death was due to an infectious disease that was the main cause of death in Brazil in the 1950s.

\section{References}

1. Araujo AM. Dicionário das artes plásticas no Paraná. Curitiba: Edição do Autor, 2006. Vol. 1

2. Coelho A. Anatomia e fisiologia patológicas.

In: Costa IA, Lima EC, organizers. O ensino

da Medicina na Universidade Federal do Paraná. Curitiba: Ed. UFPR;

1992. p. $100-4$.
3. Torres L. F. B. Historia da patologia no Paraná. In: Franco MF; Soares FA, editors. A historia da patologia no Brasil. São Paulo: Sociedade Brasileira de Patologia; 2001. p. 10-23.

4. Letti N. História da Faculdade de Medicina da UFRGS. 2010 [cited 2015 Mar 9]. Available from: http://antoniovalsalva.blogspot.com. br/2010/04/o-prof-paulo-tibirica.html 
5. Bartlett JG. Anaerobic bacterial infections of the lung. Chest.1987 Jun;91(6):901-9. https://doi.org/10.1378/chest.91.6.901

6. McConnell TH. The nature of disease: pathology for the health professions. Baltimore: Lippincott Williams \& Wilkins; 2014.

7. Tyler KL. A history of bacterial meningitis. Handb Clin Neurol. 2009;95:417-33. https://doi.org/10.1016/S0072-9752(08)02128-3
8. Carmo EH, Barreto ML, Silva Junior JB. Mudanças nos padrões de morbimortalidade da população brasileira: os desafios para um novo século. Epidemiol Serv Saúde. 2003;12:63-75.

9. World Health Organization - WHO. The top 10 causes of death Fact sheet N`310 Updated May 2014 [cited 2015 Mar 9]. Available from: http://www.who.int/mediacentre/factsheets/fs310/en/ 